\title{
Patterns of Integrated Planning and Development of Agricultural Districts in Calabria: a Case Study
}

\author{
Giuseppe Critelli ${ }^{1, a}$, Cosimo Cuomo ${ }^{2, b}$, \\ Vincenzo Mancuso $^{3, \mathrm{c}}$ and Claudio Marcianò ${ }^{4, \mathrm{~d}}$ \\ ${ }^{1}$ PAU Department, Mediterranean University of Reggio Calabria, Salita Melissari - 89124 Reggio \\ Calabria, Italy \\ ${ }^{2}$ Department of Labor Policies and Labor Market, Calabria Region, Via Lucrezia della Valle - 88100 \\ Catanzaro, Italy \\ ${ }^{3}$ Consultant for the Regional Commission against undeclared work, Via Monte San Michele n.3 \\ 87100 Cosenza, Italy \\ ${ }^{4}$ Agraria Department, Mediterranean University of Reggio Calabria, Feo de Vito, 89122 Reggio \\ Calabria, Italy \\ agiuseppe.critelli@unirc.it, ${ }^{b}$ c.cuomo@regcal.it, 'gvmancuso@gmail.com, \\ dclaudio.marciano@unirc.it
}

Keywords: Integrated planning, Agro-Food Districts, Rural Districts.

\begin{abstract}
In the last years it has grown the interest toward new forms of governance and integrated planning of the rural space. Among these, in Italy, there is a growing interest toward the definition of Rural Districts (DIRU) and Quality Agro-food District (DAQ), two innovative instruments that can play a major role in the development of the rural and agro-food economy. The paper points out the strategies defined for the development of a DIRU and a DAQ in a Calabrian area that has experienced over the years several forms of integrated planning.
\end{abstract}

\section{Introduction}

The current economic model, referable to the "New Knowledge Economy"[1], is substantially founded on the industries at high intensity of knowledge, which have even more economic relevance than the traditional industrial sectors of mass production [2]. This new approach affects, for different reasons, the farming and agro-food sector, where they stand out more and more the messages of the "product of quality" [3]. These typologies of product are identified in the productions of Denomination of Origin, the main features of which are the quality and the identity of a certain place, strong reference in a perspective of local development. The local development is one of the key concepts of the economic and social research of the last years, a concept which encloses a variety of meanings, above all linked to the identity of a territory [4]. In this context, it has come out that, among the instruments for the local development in the farming and agro-food field, both the district typologies of Rural District (DIRU) and Quality Agro-Food District (DAQ), represent two innovative instruments of governance and integrated territorial planning that can play an important role in the development of rural and agro-food economy in Italy [5]. The DIRU represents an innovative instrument and can be considered an advanced model of development and support to the rural economy, because it succeeds in being an instrument of synthesis for all those processes of development of a certain local system of rural type which goes towards what it can be defined as "modern rurality". Similarly, the DAQ too intends to give light again to the "centrality of the territory", through the realization of a whole strategic area design addressed towards the building of a governance, inside which it is possible to concentrate and integrate the organizational efforts and the own instruments of the local development. The present study summarizes the strategies of development and valorization adopted by the Lametina area of Calabria Region, South Italy, outlined to encourage the institution of a DIRU in the Reventino montainous area, and a DAQ in the lowland territories around the city of Lamezia. 


\section{Processes of territorial integrated planning in the Lametino area}

The processes of integrated planning, rather numerous during the years in this very active area, have promoted a growing awareness of the local identity values, which today find themselves at the basis of many instruments of intervention in the different programs and plans of local development.

These integrated planning activities transformed the area from a simple geographical cluster into a Local System where the developing strategies adopted gave to the various sectors operating in the area the possibility to contribute to the definition of a Territorial System of the Lametino [6].

The carrying out and the development of integrated plans and programs, during the years had allowed the territory to address peculiar needs towards wider views, addressed towards a net-structuring of the local productions in an optimal interaction between public and private subjects. An important advantage, in fact, of the territorial aggregation is linked to the necessity to reach a critical mass of productions, indispensable factor of success to face the markets, above all the international ones.

The territorial platform set up in the area can be considered a strong and dynamic reality with a standing out ability to read the current territorial processes, besides having originated an innovative process. Through such a long process of development it has taken shape the strategy of the Lametino area, more meaningful also in the light of the variegated composition of the local system of the Lametino, which shows different territorial components: mountainous internal area (north), coastal area, comprehensive urban area of Lamezia Terme, plain field, rural inner area (south). It appears evident how the synergy among research, innovation and local production, implemented in these last years, gives the hints for a modern re-launch of the agro-food supply chain and an accomplished territorial integrated cohesion, in a perspective of local productive system in conformity with the principles established by the law setting up the District, and for this reason "characterized by a strong integration between farming activities and other local activities, and also the production of goods and services of particular specificity, coherent with the traditions and the natural vocations of the territory".

In this sense, it has been possible to consider the concrete possibility to set up Districts able to be a model of development in continuity with the previous integrated planning experiences. In particular, it is interesting that, after the setting up of the Lametino DAQ (Regional Council Decision n. 520 of the 11/11/2011) and Reventino DIRU (Regional Council Decision n. 403 of the 11/11/2013), they are entirely instruments of planning and governance able to implement a real perspective of development for the whole territory in order to: a) give value to the farming and agro-food productions; $b$ ) encourage the concentration of the supply according to supply chain and multi-supply chain views; c) arrange service infrastructural conditions related to the needs of farming and agro-food productions; d) provide technical instruments to encourage investments having as main purpose the strengthening of the relations among agro-food enterprises and the firms' support on the national and international markets.

\section{Institutional involvement for the Districts' pointing out and promotion}

In the orientation taken to point out and promote both the DAQ in the Lametino and the DIRU in the Reventino, we have been exploiting the experience developed in the different processes of integrated planning which have been consolidating the net of relations among public and private subjects which operate in the territory. The planning process which has been followed during the years, thanks to the intensifying of the opportunities of exchange the Lametino area has put in place, has allowed the proposal of the two Districts. In particular, in the whole area, during the time, it has been built a horizontal process through an ongoing action of accompanying and territorial animation able to define a strategy of total local development and start a dynamic process of consultation and cooperation among the different subjects operating in the territory.

As regards the DAQ, these activities have started since 2007, under the initiative of the agency of local development "Lametia Sviluppo", which has organized a series of initiatives (theme meetings 
and territorial studies in depth) in order to animate the territory and sensitize the economic operators. As for the DIRU, instead, the activities have been coordinated by the Reventino LAG as Promoting Board, and have always been based both on the institutional participation and the single individuals, besides the other initiatives which have strengthened the strategy and given place to all the preparatory and consequential activities.

During such meetings, for both the district situations they have come out the needs in terms of territorial requirements, and the requests of valorization and re-launch of the local economical, social and cultural resources. In order to let the territorial animation step be more operational, the two agencies promoters of the process of integrated planning, Lametia Sviluppo and Reventino LAG, have been making operational, each one in its own area and in different periods, an itinerant office gathering useful elements for identifying territorial needs and promoting meetings among the interested parts for an institutional involvement.

The itinerant office has made easy the steps of institutional concertation and aggregation of the constituent organs, as established by the norms of reference, as condition not to be set aside for the constitution of the DAQ in Lametino and DIRU in Reventino. With regard to that, the methodology related to the structure of accompanying and territorial animation is characterized by two meeting typologies: bilateral or multilateral meetings with the different agencies of territorial development and the subjects requesting further explanation (municipalities, associations, etc.); meetings organized through the institution of a permanent Board of concertation, where the institutional subjects and the representatives of the economical, social, labor and cultural forces have been represented.

The activities of animation carried out allowed to give life to territorial integrated routes of different nature (institutional, productive, technical-scientific, social, cultural), sensitive to the development of the territory and able to give support to the demand, achieve common objectives, and have generated, moreover, from one hand expectations of development of the area under concern and, on the other hand, the worrying that both the proposals were in keeping with a long-breathing planning, so not only linked to the contingent planning of the District setting up, but addressed to a homogeneous development of the area. The activity of accompanying, animation and involvement has generated in the territory a process of strengthening either of the system of relations among local institution, or of the system of enterprises which allowed a major coordination and a wider sharing of the objectives, besides a broad-minded perspective as to the economic-productive realities present in the territorial field of reference.

\section{Profile of the territory and the productive vocations}

The area of the Local Lametino System, as for the DAQ and DIRU institution, characterizes itself for the lasting of a variety of productive vocations related to the so-called farming supply chains and the agro-industrial ones, or all those referable to the primary sector. The territory pointed out for the two different district aggregations, during the planning steps and from the preparatory study, is represented by the aggregation of 10 municipalities for the DAQ and 18 for the DIRU with a whole population of about 140.000 inhabitants (Fig. 1).

The whole area represents a portion of the regional territory of reduced dimensions which, answering to widespread similarities of rural type, is included in the Rural Development Program (RDP) of Calabria Region with three macro-areas: "Rural areas with overall problems of development" and "Internal rural areas" (as for the DIRU) and "Areas with intensive and specialized agriculture" for the DAQ and the closest area to Lamezia.

The territorial features of the Lametino Local System have been reported in table 1, where the RDP Zoning includes (Table 1):

- A) Urban clusters; B) Rural areas and intensive and specialized Agriculture; C) Internal rural areas;

D) Rural areas with overall problems of development; 
In table the Extended Altitude Area refers to:

-1) Intense mountain; 2) Coastal mountain; 3) Intense hill; 4) Coastal hill; 5) Flat area.

Table 1 - Municipalities of the Reventino Rural District and the Lametino Agro-Food District

\begin{tabular}{|c|c|c|c|c|c|c|c|c|c|c|c|}
\hline \multirow[b]{2}{*}{ n. } & \multirow[b]{2}{*}{ Municipality } & \multirow[b]{2}{*}{ Province } & \multicolumn{4}{|c|}{$\begin{array}{c}\text { RDP Zoning } \\
2007-2013\end{array}$} & \multirow{2}{*}{$\begin{array}{c}\text { Population } \\
2011 \\
\text { (number of } \\
\text { inhabitants) }\end{array}$} & \multirow{2}{*}{$\begin{array}{l}\text { Extended } \\
\text { Altimetric } \\
\text { area }\end{array}$} & \multicolumn{3}{|c|}{ Altimetry } \\
\hline & & & A & $\mathrm{B}$ & $\mathrm{C}$ & $\mathrm{D}$ & & & $\begin{array}{l}\text { Level of altitude } \\
\text { of the center } \\
\text { (meters) }\end{array}$ & $\begin{array}{l}\text { Minimum } \\
\text { alt. level } \\
\text { (meters) }\end{array}$ & $\begin{array}{c}\text { Maximun } \\
\text { altitude level } \\
\text { (meters) }\end{array}$ \\
\hline \multicolumn{12}{|c|}{ REVENTINO RURAL DISTRICT } \\
\hline 1 & Amato & $\mathrm{CZ}$ & - & - & - & $\mathrm{X}$ & 837 & 3 & 480 & 95 & 1.035 \\
\hline 2 & Carlopoli & $\mathrm{CZ}$ & - & - & - & $\mathrm{X}$ & 1.622 & 1 & 924 & 624 & 1.075 \\
\hline 3 & Cicala & $\mathrm{CZ}$ & - & - & - & $\mathrm{X}$ & 1.008 & 1 & 829 & 550 & 1.088 \\
\hline 4 & Conflenti & $\mathrm{CZ}$ & - & - & - & $\mathrm{X}$ & 1.437 & 1 & 540 & 235 & 1.410 \\
\hline 5 & Decollatura & $\mathrm{CZ}$ & - & - & - & $\mathrm{X}$ & 3.252 & 1 & 765 & 663 & 1.366 \\
\hline 6 & Gimigliano & $\mathrm{CZ}$ & - & - & - & $\mathrm{X}$ & 3.421 & 1 & 500 & 200 & 968 \\
\hline 7 & Marcellinara & $\mathrm{CZ}$ & - & - & - & $\mathrm{X}$ & 2.253 & 3 & 337 & 87 & 527 \\
\hline 8 & Martirano & $\mathrm{CZ}$ & - & - & $\mathrm{X}$ & - & 937 & 1 & 381 & 138 & 942 \\
\hline 9 & Martirano L. & $\mathrm{CZ}$ & - & - & $\mathrm{X}$ & - & 1.167 & 1 & 520 & 97 & 1.279 \\
\hline 10 & Miglierina & $\mathrm{CZ}$ & - & - & - & $\mathrm{X}$ & 799 & 3 & 575 & 150 & 1.039 \\
\hline 11 & Motta S.L. & $\mathrm{CZ}$ & - & - & - & $\mathrm{X}$ & 871 & 1 & 590 & 165 & 1.352 \\
\hline 12 & Platania & $\mathrm{CZ}$ & - & - & - & $\mathrm{X}$ & 2.232 & 1 & 750 & 350 & 1.417 \\
\hline 13 & S. Mango d'A. & $\mathrm{CZ}$ & - & - & $\mathrm{X}$ & - & 1.639 & 4 & 468 & 48 & 1.100 \\
\hline 14 & San Pietro A. & $\mathrm{CZ}$ & - & - & - & $\mathrm{X}$ & 1.778 & 1 & 750 & 350 & 1.417 \\
\hline 15 & Serrastretta & $\mathrm{CZ}$ & - & - & - & $\mathrm{X}$ & 3.249 & 1 & 840 & 100 & 1.198 \\
\hline 16 & Settingiano & $\mathrm{CZ}$ & - & - & - & $\mathrm{X}$ & 2.955 & 3 & 270 & 52 & 528 \\
\hline 17 & Soveria Mann. & $\mathrm{CZ}$ & - & - & - & $\mathrm{X}$ & 3.137 & 1 & 774 & 695 & 1.000 \\
\hline 18 & Tiriolo & $\mathrm{CZ}$ & - & - & - & $\mathrm{X}$ & 3.897 & 3 & 690 & 69 & 950 \\
\hline \multicolumn{2}{|c|}{ Area } & - & - & - & - & - & 36.491 & - & - & - & - \\
\hline \multicolumn{2}{|c|}{ Calabria Region } & - & - & - & - & - & 1.959 .050 & - & - & - & - \\
\hline \multicolumn{2}{|c|}{ Area/Region } & - & - & - & - & - & 1,86 & - & - & - & - \\
\hline \multicolumn{12}{|c|}{ LAMETINO AGRO FOOD DISTRICT } \\
\hline 1 & Curinga & $\mathrm{CZ}$ & - & $\mathrm{X}$ & - & - & 6.708 & 4 & 35 & 0 & 725 \\
\hline 2 & Falerna & $\mathrm{CZ}$ & - & $\mathrm{X}$ & - & - & 3.801 & 4 & 550 & 0 & 1.327 \\
\hline 3 & Feroleto A. & $\mathrm{CZ}$ & - & $\mathrm{X}$ & - & - & 2.087 & 3 & 280 & 33 & 825 \\
\hline 4 & Gizzeria & $\mathrm{CZ}$ & - & $\mathrm{X}$ & - & - & 4.522 & 4 & 630 & 0 & 1.290 \\
\hline 5 & Iacurso & $\mathrm{CZ}$ & - & $\mathrm{X}$ & - & - & 623 & 3 & 441 & 150 & 925 \\
\hline 6 & Lamezia Terme & $\mathrm{CZ}$ & - & $\mathrm{X}$ & - & - & 70.336 & 5 & 216 & 0 & 1.311 \\
\hline 7 & Maida & $\mathrm{CZ}$ & - & $\mathrm{X}$ & - & - & 4.457 & 3 & 299 & 30 & 525 \\
\hline 8 & Nocera Ter. & $\mathrm{CZ}$ & - & $\mathrm{X}$ & - & - & 4.725 & 4 & 240 & 0 & 1.327 \\
\hline 9 & Pianopoli & $\mathrm{CZ}$ & - & $\mathrm{X}$ & - & - & 2.559 & 3 & 250 & 62 & 600 \\
\hline 10 & San Pietro a M. & $\mathrm{CZ}$ & - & $\mathrm{X}$ & - & - & 4.298 & 1 & 355 & 19 & 625 \\
\hline \multicolumn{2}{|c|}{ Area } & - & - & - & - & - & 104.116 & - & - & - & - \\
\hline \multicolumn{2}{|c|}{ Calabria Region } & - & - & - & - & - & 1.959 .050 & - & - & - & - \\
\hline \multicolumn{2}{|c|}{ Area/Region } & - & - & - & - & - & 5,31 & - & - & - & - \\
\hline
\end{tabular}

The Reventino DIRU comprehends mainly mountainous territory, with some hilly areas. The territory comprehends almost all the Reventino Massif and overlooks the Sant'Eufemia plain and the Catanzaro-Lamezia Isthmus. The area under concern is potentially a promoting centre of regional development, due to the particular vocations of the rural area with district potentialities.

The Lametino DAQ comprehends mainly flat land with some hilly areas where, due to a characteristic proper of the Calabrian settlement systems, they are found "historic" urban centres of limited "urban" extension. Analyzing the single geo entity it comes out that in this area in falls a real city, Lamezia Terme, with a population over 70.000 inhabitants, real attractor of generalized fluxes and service cluster for services to people and enterprises. 


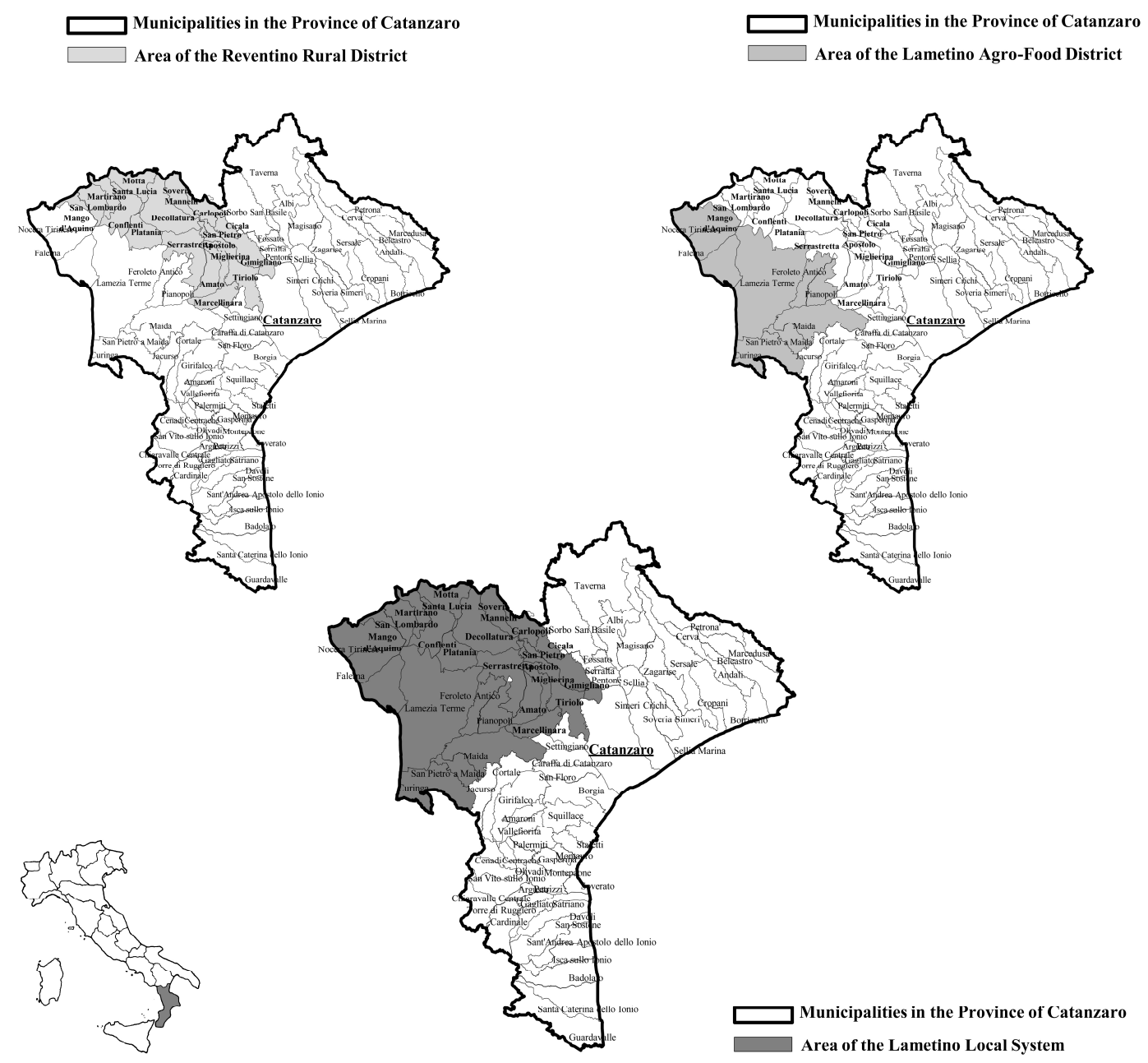

Fig. $1-$ The area of study

As far as it concerns the farming vocation and the main farming supply chains, the engine of the Lametino Local System, we have to underline that they distinguish themselves clearly than other areas of farming production in Calabria for the co-existence of a wide range of productions that, for needs of synthesis and similar matters, can be embraced in two main groups:

- $\quad$ The supply chains of the commodities - all those products also object of negotiation and exchange even at long distances thanks to their feature of being easily stored and not so easily differentiable (chestnuts, salami, dairy products, potatoes from Sila etc.);

- The supply chains of typical products and/or traditional - all those products from which the typicalness can occur only in its own territory of reference (in the case of the Lametino Local System: wine, olive oil, salami, cheese, products of the apiculture, chestnut) or those products the typicalness of which, besides on a territorial basis, can occur also on an industrial basis (for example milk for fresh consumption).

The characteristic that the two groups of supply chains have in common is "quality" as the basis typicalness and the link with the territory, main elements on which to foster eventual processes of internationalization. In this direction it has a great importance the use of distinctive brands and signs, either of private imprint (individual and collective brands), or referred to regulations procedures like DOC, DOP and IGP. Worth of evidence it is also the effort made towards the biological productions and the integrated biological fight. The territory considered is characterized by the presence of an intense level of farming activities which give birth to recognized, certified and protected productions, according to the European regulations and national regulations. 
In particular, they are products: Agro-food Products defined Traditional (PAT) recognized by the Ministerial Decree 18 July 2000; agro-food products marked by the Denomination of Protected Origin (DOP) and the Geographical Protected Indication (IGP); wines with the Denomination of Controlled Origin and Typical Geographical Indication. In the territory of the Lametino Local System they are recorded the productions of five products with DOP trademark and three products with the IGP one, as indicated in Table 2, in which for each production they are reported the details of reference by the European Union. As regards to the wine-growing production, the Lametino territory assures the production of three wines with Denomination of Controlled Origin (DOC) and one with Typical Geographical Indication, as marked in Table 3.

Table 2 - List of quality productions enrolled in the reference registers falling into the Lametino Local System

\begin{tabular}{|c|c|c|c|c|c|c|}
\hline Product & Type & Ty pology & $\begin{array}{r}\text { CE Regulation } \\
\text { DOI }\end{array}$ & $\begin{array}{l}\text { Publication in the Offical } \\
\text { Journal of the Europea n } \\
\text { Union (GUCE) } \\
\text { Products }\end{array}$ & Region & Province \\
\hline $\begin{array}{l}\text { Cap ocollo di } \\
\text { Calabria }\end{array}$ & D.O.P. & Processed meat & $\begin{array}{l}\text { CE Reg. n. } 134 \\
20.01 .98\end{array}$ & GUCE L. 15 of 21.01 .98 & Calabria & $\begin{array}{l}\text { Catanzaro, Cosenza, } \\
\text { Croton e, Reggio Calabria, } \\
\text { Vibo Valentia }\end{array}$ \\
\hline $\begin{array}{l}\text { Pancetta di } \\
\text { Calabria }\end{array}$ & D.O.P. & Processed meat & $\begin{array}{l}\text { CEReg. n. } 134 \\
20.01 .98\end{array}$ & GUCE L. 15 of 21.01 .98 & Calabria & $\begin{array}{l}\text { Catanzaro, Cosenza, } \\
\text { Croton e, Reggio Calabria, } \\
\text { Vibo Valentia }\end{array}$ \\
\hline $\begin{array}{l}\text { Soppress ata di } \\
\text { Calabria }\end{array}$ & D.O.P. & Meat products & $\begin{array}{l}\text { CEReg. n. } 134 \\
20.01 .98\end{array}$ & GUCE L 15 of 21.01 .98 & Calabria & $\begin{array}{l}\text { Catanzaro, Cosenza, } \\
\text { Croton e, Reggio Calabria, } \\
\text { Vibo Valentia }\end{array}$ \\
\hline $\begin{array}{l}\text { Salsiccia di } \\
\text { Calabria }\end{array}$ & D.O.P. & Processed meat & $\begin{array}{l}\text { CEReg. n. } 134 \\
20.01 .98\end{array}$ & GUCE L. 15 of 21.01 .98 & Calabria & $\begin{array}{l}\text { Catanzaro, Cosenza, } \\
\text { Croton e, Reggio Calabria, } \\
\text { Vibo Valentia }\end{array}$ \\
\hline Lametia & D.O.P. & Oils and fats & $\begin{array}{l}\text { CER Reg. n. } \\
210704.10 .99\end{array}$ & GUCE L 258 of 05.10 .99 & Calabria & Catanzaro \\
\hline \multicolumn{7}{|c|}{ IGP Products } \\
\hline Patat a della Sila & I.G.P. & $\begin{array}{l}\text { Fruit and } \\
\text { vegetables and } \\
\text { cereals }\end{array}$ & $\begin{array}{l}\text { CE Reg. n. } 898 \\
08.10 .10\end{array}$ & GUCE L 266 of 09.10 .10 & Calabria & $\begin{array}{l}\text { Catanzaro, Cosenza, Vibo } \\
\text { Valentia }\end{array}$ \\
\hline $\begin{array}{l}\text { Cipolla Rossa di } \\
\text { Tropea Calabria }\end{array}$ & I.G.P. & $\begin{array}{l}\text { Fruit and } \\
\text { vegetables and } \\
\text { cereals }\end{array}$ & $\begin{array}{l}\text { CE Reg. n. } 284 \\
27.03 .08\end{array}$ & GUCE L. 86 of 28.03 .08 & Calabria & $\begin{array}{l}\text { Catanzaro, Cosenza, Vibo } \\
\text { Valentia }\end{array}$ \\
\hline $\begin{array}{l}\text { Clementine di } \\
\text { Calabria }\end{array}$ & I.G.P. & $\begin{array}{l}\text { Fruit and } \\
\text { vegetables and } \\
\text { cereals }\end{array}$ & $\begin{array}{l}\text { CE Reg. n. } \\
2325 \text { del } 24.1\end{array}$ & GUCE L. 322 of 25.11 .97 & Calabria & $\begin{array}{l}\text { Reggio Calabria, } \\
\text { Catanzaro, Cosenza, Vibo } \\
\text { Valenzia, Crotone }\end{array}$ \\
\hline
\end{tabular}

Source MIPAAF

Table 3 - List of Doc and Igt wines falling into the Lametino Local System

\begin{tabular}{|c|c|c|c|}
\hline Product & Category & Decree & Description \\
\hline Lamezia & D.O.C. & D.M. 2/5/1995 & $\begin{array}{l}\text { The grapes for the production of DOC wines "Lamezia" must } \\
\text { be in the following Municipalities Curinga, Falerna, Feroleto } \\
\text { Antico, Gizzeria, Francavilla Angitola, Maida, Pianopoli, } \\
\text { Lamezia Terme, San Pietro a Maida }\end{array}$ \\
\hline Scavigna & D.O.C. & $\begin{array}{l}\text { D.M. } 17 / 10 / 1994 \\
\text { Modified on } 12 / 5 / 1995\end{array}$ & $\begin{array}{l}\text { The grapes for the production of DOC wines "Scavigna" must } \\
\text { be in the followingMunicipalities Nocera Terinese Falerna }\end{array}$ \\
\hline Savuto & D.O.C. & D.P.R 19/5/1975 & $\begin{array}{l}\text { The grapes must be grown in the production area, which } \\
\text { includes part of the territory of the municipalities of } \\
\text { Rogliano, S.Stefano di Rogliano, Marzi, Belsito, Grimaldi, } \\
\text { Altilia, Aiello Calabro, Cleto, Serra Aiello, Pedivigliano, } \\
\text { Malito, Amantea, Scigliano, Carpanzano; Motta S.Lucia, } \\
\text { Martirano Vecchio, Martirano Lombardo, S.Mango d' } \\
\text { Aquino, Nocera Terinese e Conflenti }\end{array}$ \\
\hline Val D'Amato & I.G.T. & D.M. 27/12/1995 & $\begin{array}{l}\text { The production area of Val d'Amato is related to the } \\
\text { Municipalities of: Lamezia Terme, Maida, San Pietro a } \\
\text { Maida, Curinga, Pianopoli, Feroleto Antico e Gizzeria }\end{array}$ \\
\hline
\end{tabular}




\section{Conclusions}

The two Districts of the area, Lametino DAQ and Reventino DIRU, generated at the end of a very incisive integrated process and with the objective of guaranteeing a governance which could charge itself with the promotion and the auto-propelling development of the enterprises of the territory. The Lametino is surely an intelligent territory which, through the processes of integrated planning, has shown to acquire awareness within the opportunities of development and growth of the same territory and of local firms. In particular, the district form can carry out its function of governance through a development program characterized by fundamental actions in terms of logistics, education, research, transfer of product and process innovations, internationalization.

All this considering that, in an economical system made more and more competitive by phenomena of globalization, the productive vocation of an area and the availability of productions in a certain time line, are necessary conditions, but no more enough to defend the market shares acquired by the market operators. In this sense, the two districts' task will be to obtain the maximum involvement of entrepreneurs and economical operators, creating networks among the different private actors, the organizations and the boards present in the territory, completing the process which has led to the District setting up. In this direction, it will be opportune to realize forms of aggregation of the different actors, for example through Consortia Companies able to put in place the necessary Projects of Supply chain to give a concrete form to the Logistic Platform of the Lametino area, developing the social capital and the system of competences in service for the agriculture, through the instrument of the district governance and, in particular, the Company of District, which will work as Centre of Services in a transversal way, within the different supply chains pointed out.

\section{References}

[1] J. Mokyr, The Gifts of Athena: Historical Origins of Knowledge Economy, Princeton, Princeton University Press, (2002)

[2] P.A. David and D. Foray: Economic Fundamentals of the Knowledge Society. In: Policy Futures in Education, I (2003), 20-49

[3] G. Critelli and C. Marcianò: Economia della Conoscenza, sviluppo locale e pianificazione territoriale integrata: i prodotti di qualità nell'istituzione dei Distretti agroalimentari. In: C. Marcianò (Ed.): Governance rurali in Calabria, Università degli Studi Mediterranea di Reggio Calabria, Centro Stampa di Ateneo, (2013)

[4] A. Cammozzo: L'identità nello sviluppo, unpublished report, (2008), Information on http://www.academia.edu/3038439/Lidentita_nello_sviluppo

[5] G. Gulisano and C. Marcianò: I distretti rurali in Calabria. Aspetti teorici, metodologici ed applicativi, Kalit, Reggio Calabria, (2008). Information on http://www.pical.unirc.it

[6] V. Carè: Il Progetto Integrato per le Aree Rurali dei Monti Reventino-Tiriolo-Mancuso. In: C. Marcianò (Ed.): Governance rurali in Calabria, Università degli Studi Mediterranea di Reggio Calabria, Centro Stampa di Ateneo, (2013) 